\title{
Petroleum resources in the Japanese island-arc setting
}

Japan's domestic oil and gas production covers only a small part of the nation's demand. However, a great deal of exploration effort over more than a century has led to the discovery of approximately 100 oil and gas fields, although most of them have been depleted. Domestic oil and gas production in 1989 was 1,755 kiloliters per day and 5.5 million cubic meters per day, respectively. Most of the oil and gas fields have been found in Neogene onshore sedimentary basins on the Sea of Japan side of northern Honshu.

Several hydrocarbon accumulations have been discovered in uncommon reservoirs, such as in nonstructurally controlled dissolved-in-water gas reservoirs and in deep-seated volcanic and volcaniclastic reservoirs. The volcanic reservoirs are now the most important objectives for petroleum exploration in Japan because they retain favorable porosities even below 4,000 meters and produce commercially significant amounts of gas. Such deep-seated Miocene volcanic-rock reservoirs will continue to be the main exploration target in onshore basins. In addition, Tertiary clastic deposits in offshore sedimentary basins and Cretaceous and Paleogene sequences in Hokkaido are important objects for exploration.

\section{Tectonic setting}

$J_{\text {apan is located on the western margin of the Pacific Ocean, and }}$ subduction-related basins are developed both onshore and offshore. The numerous sedimentary basins in Japan contain mostly Neogene sequences. Among them, the sedimentary basins developed along the Sea of Japan in northern Honshu, the main island of Japan, are particularly important for petroleum exploration.

Relatively undeformed sections occur in forearc basins along the Pacific Ocean, whereas deformed sections occur in the backarc basins along the Sea of Japan (fig. 1). Major folds and associated faults in the backarc basins have north-northeast-south-southwest trends that are consistent with the present-day east-west compressional stress. The structural trends of all Neogene sedimentary basins are generally dependent on the basement structure.

In most of the Neogene sedimentary basins along the Sea of Japan, intense submarine volcanism, presumably related to the open-

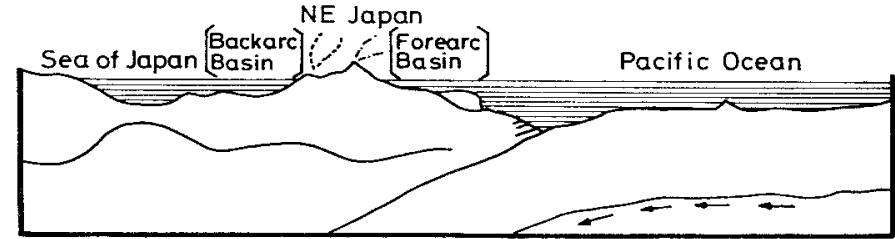

Figure 1.-Tectonic setting of the Japan island arc showing areas of volcanic activity (below dashed lines) and subduction (arrows). Abbreviation: $N E$, northeast.

ing of the Sea of Japan during early middle Miocene time, produced a large amount of volcanic rock. These volcanic rocks have been called "Green Tuffs" because of their green color, which results from chlorite and sericite alteration products (fig. 2).

The Neogene tectonic settings of Japan are characterized by low heat flows in the forearc basins, which have current general geothermal gradients ranging from 1.8 to $2.2{ }^{\circ} \mathrm{C} / 100 \mathrm{~m}$, and by high heat flows in the backarc basins, which have geothermal gradients ranging from 3.0 to $5.5^{\circ} \mathrm{C} / 100 \mathrm{~m}$ (and some exceptionally high values up to $6.7^{\circ} \mathrm{C} / 100 \mathrm{~m}$ ). Source beds in the forearc basins tend to be thermally immature (Dickinson and Seeley, 1979). Therefore, at a given thermal maturity level, the conditions for hydrocarbon migration and accumulation are more favorable in the backarc basins than in the forearc basins because the former could retain higher porosity. Similar tectonic settings probably dominated throughout Neogene time, although detailed tectonic reconstruction of the basins has been a subject of long debate. Most of the Neogene backarc sedimentary basins contain varying quantities of volcanic materials derived from volcanic activity that occurred intermittently throughout the histories of the basins.

\section{Sedimentary basins}

The basement rocks of the Neogene sections of backarc basins are Paleozoic metamorphic and nonmetamorphic rocks and Cretaceous granitic rocks. In general, the basement rocks were faulted, were tilted, and subsided at the beginning of the deposition of the Neogene sections.

The area of offshore sedimentary basins approximately equals Japan's total land area of nearly $380,000 \mathrm{~km}^{2}$, whereas onshore Neogene sedimentary basins occupy only 10 percent of the total land area (fig. 3). The basins extending to the southwest of Kyushu (not fully shown in fig. 3) have vast sedimentary areas.

The thickness of Neogene sections varies from place to place but generally is on the order of several thousand meters. The deepest well to date was drilled to a depth of $6,004 \mathrm{~m}$ in the onshore Niigata area on the Sea of Japan side of northern Honshu (fig. 2), but it did not penetrate the entire Neogene section. More than 7,000 m of Neogene section is expected in such areas. 


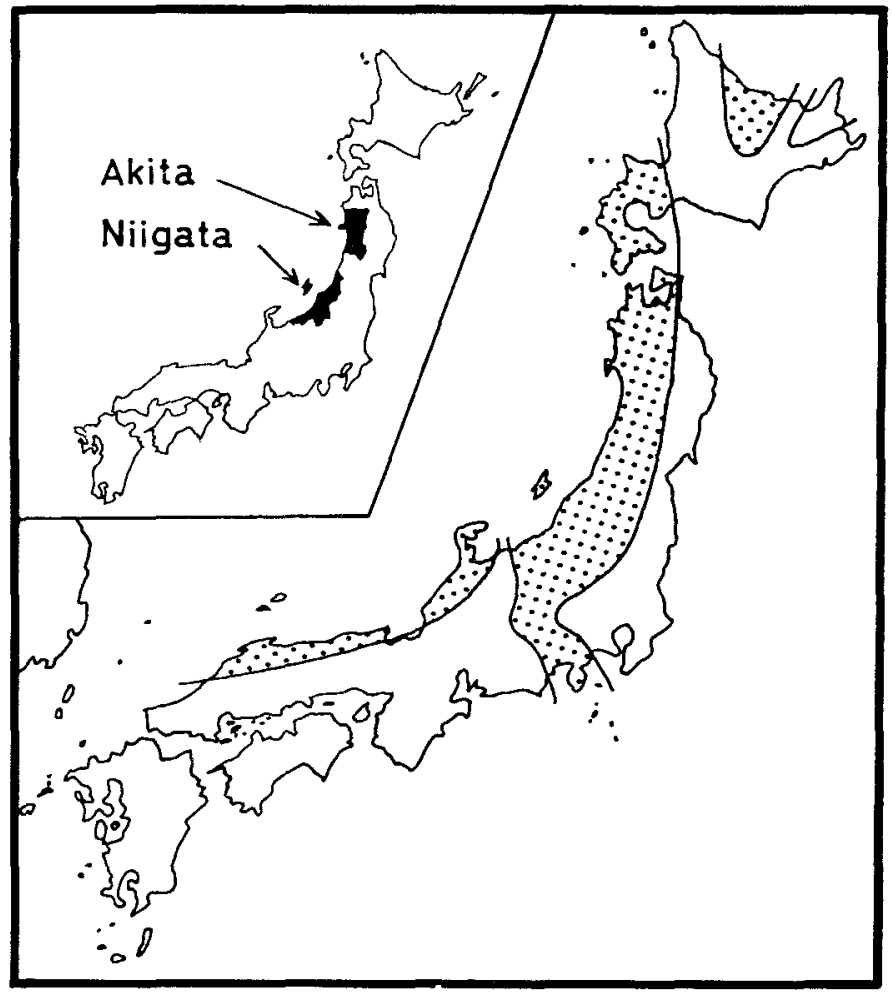

Figure 2. -Distribution of the so-called "Green Tuff" region (stippled areas) in Japan. Inset shows the major petroleum-producing areas, Akita and Niigata.

Neogene sections in the "Green Tuff" region have a general similarity in their style of geologic development, although small differences are observed in sedimentary facies, amount of sediment, mode and period of volcanic activity, and nature and timing of tectonic movement.

\section{Stratigraphy and volcanic reservoirs}

The stratigraphy of the Neogene sections in the Niigata area (fig. 2), a part of the "Green Tuff" region along the Sea of Japan in northern Honshu, is summarized in figure 4 as an example. Sections ranging in age from Miocene through Pleistocene are divided into the $\mathrm{Mi}$ kawa Group, the Tsugawa-Nanatani, Teradomari, Shiiya, Nishiyama, and Haizume Formations, and the Uonuma Group in ascending order (Ikebe and Maiya, 1981). During the early Miocene to early middle Miocene, volcanic rocks (the so-called "Green Tuffs") were laid down. These volcanic rocks were covered by black or siliceous marine shales of the Nanatani and Teradomari Formations that were deposited in a stagnant marine environment. The source rocks for Neogene oil and gas are probably these shales of middle Miocene age. The Shiiya and Nishiyama Formations consist mostly of siliciclastic rocks, including turbidite sandstone reservoirs.

Regional correlations of these strata have been done by using lithological characteristics and planktonic and benthic foraminifers. In general, shaly sections older than late Miocene or the Pliocene are overpressured to various degrees. Miocene volcanic reservoirs of the Minami Nagaoka-Katakai gas fields in the Niigata area are overlain by overpressured marine shales. Volcanic reservoirs of these gas fields are composed mostly of rhyolite that erupted on the sea floor. Pillow-brecciated and lava facies of rhyolite having high porosities and permeabilities are productive reservoirs (fig. 5). The porosit? values suggested by core analyses and wireline logs vary from approximately 10 to 20 percent. and they result from fractures and various types of vugs of both primary and secondary origin. The reservoirs are encountered at depths ranging from approximate: 3,900 to $4,600 \mathrm{~m}$ below mean sea level. Hyaloclastite facies, which are also hydrocarbon-bearing facies, are not sufficiently productive because of their low permeability.

Volcanic reservoirs other than rhyolite also have been reported. Basalts, for instance, which are not productive in the Niigata are.i. are good producers at the Yurihara oil and gas field in the Akita area north-northeast of Niigata (fig. 2) (Tsuchiya and others, 1989).

In general, source rocks for the deep-seated volcanic reservoir are geologically younger than the reservoirs themselves. Hence. hydrocarbons found in the deep-seated volcanic-rock reservoirs couli have migrated laterally from mature source rocks located in the depressions directly adjacent to the reservoirs. Where no direct contact exists between the source and reservoir rocks, faults might have played an important role as migration paths. In addition, some shal:intercalated with volcanic reservoirs, as observed in a well drilled in the Akita area, have some source-rock potential. The latest inform.

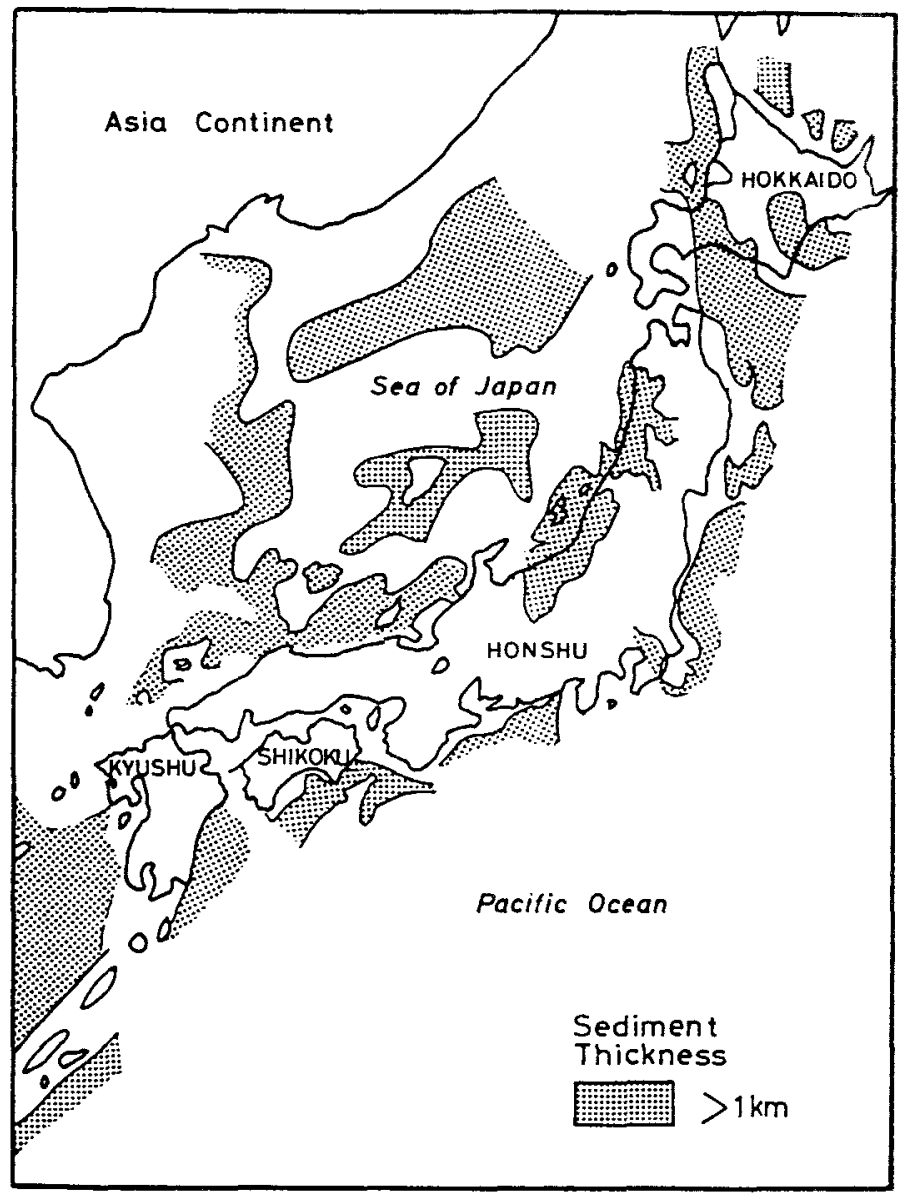

Figure 3.-Distribution of Neogene sedimentary basins (stippled pattern) of Japan and the adjacent area (modified from Ishiwada and Ogawa, 1976). 


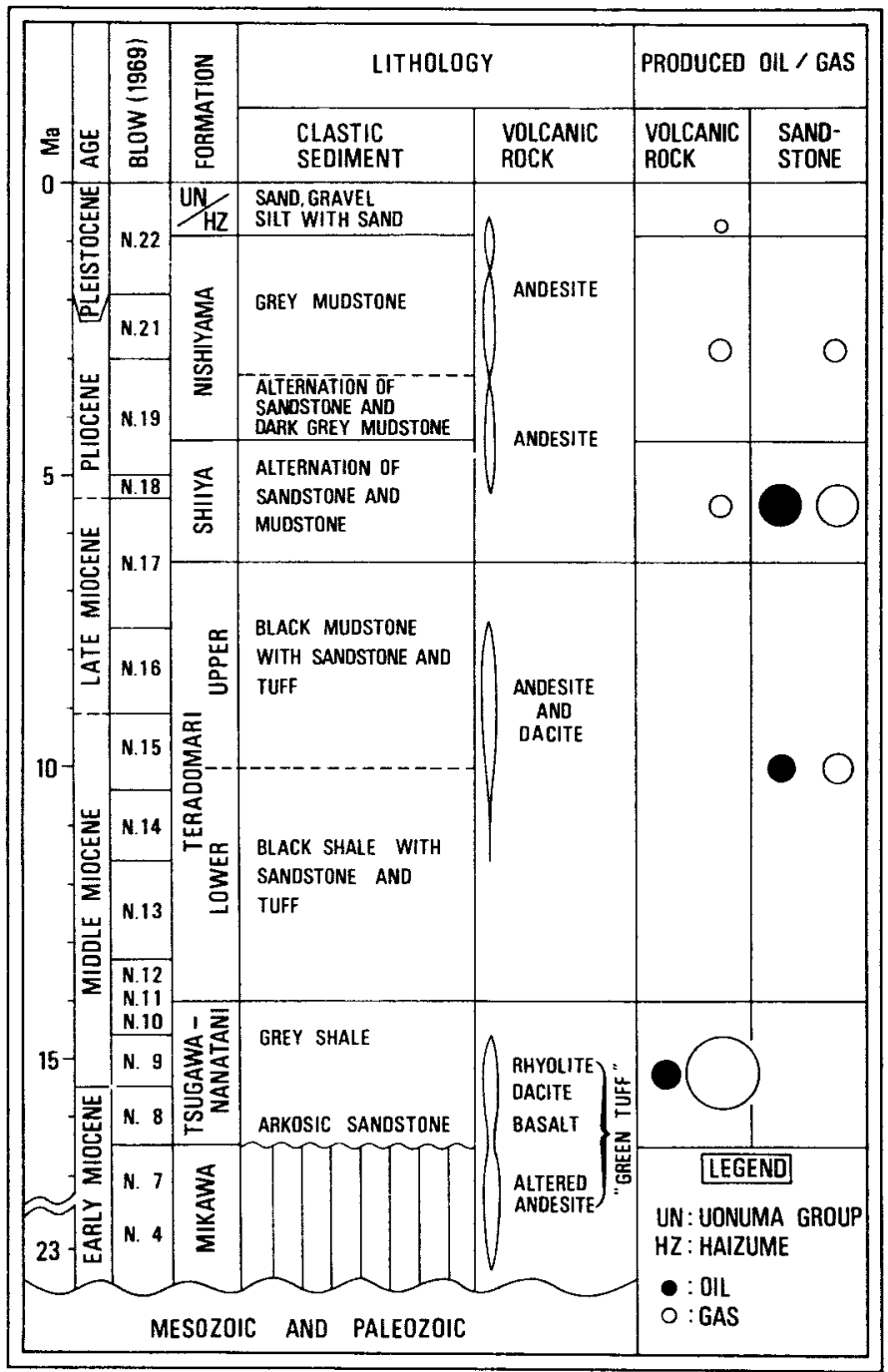

Figure 4.-Generalized stratigraphic framework of the Nigata sedimentary basin of Japan (taken from Komatsu and others, 1984). Foraminiferal zones are from Blow (1969), and relative quantities of oil and gas are shown by sizes of circles.

tion from a current well in the Niigata area suggests that shales below the main gas-productive volcanic reservoirs also show good sourcerock potential.

\section{Petroleum resources}

Japan's petroleum resources can be divided into three groups on the basis of reservoir types: gas-dissolved-in-water deposits (Marsden and Kawai, 1965), clastic-rock reservoirs, and volcanic-rock reservoirs.

Dissolved-in-water-type gases are called "suiyosei-gas" in Japanese. This type of gas deposit contains only methane and is produced together with formation waters in various gas/water ratios (generally ranging from 1 to 10 cubic meters per kiloliter $\left(\mathrm{m}^{3} / \mathrm{kL}\right.$ ) and high values up to $45 \mathrm{~m}^{3} / \mathrm{kL}$ ). Salinity of the formation waters is close to that of seawater. The areal extent of this type of gas deposit is fairly large (fig. 6). Gas-producing horizons are generally shallower than $2,500 \mathrm{~m}$ and are Miocene to Quaternary in age (Fukuta, 1977). In contrast to conventional gas reservoirs, the producing formations do not necessarily contain traditional structural traps such as anticline or fault traps. No clear relationship has been established between structural position and the gas-production rate. Gasdissolved-in-water deposits produce dry gas (methane only) and are characterized by light carbon-isotopic compositions ranging from -65 to -75 parts per thousand. The methane is, therefore, believed to have been generated as a result of bacterial activity (Nakai, 1960).

Clastic-rock reservoirs have been important contributors to oil production in Japan. These are mostly sandstone and volcaniclastic reservoirs, with the exception of deep-water carbonate reservoirs at the Fukubezawa oil field in Akita (see Aoyagi, 1985). The major sandstone reservoirs in Japan were deposited as turbidites. These reservoirs occur in backarc basins extending from Akita to Niigata on the Sea of Japan side (figs. 2 and 3). In a forearc basin on the Pacific Ocean side, commercial gas deposits are found in shallow-water sandstone reservoirs at the Iwaki gas field. However, no commercial oil field has been found in a forearc basin.

Volcanic-rock reservoirs are of importance as major gas producers. Oil and gas in volcanic rocks were discovered first at the Mitsuke field in 1958. Since this discovery, volcanic masses have been attractive targets as hydrocarbon reservoirs. Significant quantities of gas have been found in volcanic- and volcaniclastic-rock reservoirs, such as in the fields of Katakai, Kumoide, Sekihara, Fujikawa, Yoshii, Higashi Kashiwazaki, Minami Nagaoka, and Yurihara (Katahira and Ukai, 1976; Komatsu and others, 1984).

\section{Exploration activities}

In Japan, more than 1,530 exploratory wells were drilled onshore during the period from 1941 through 1989 , but only 160 were drilled offshore during the period from 1967 to 1989 . The clastic sections of the onshore Akita and Niigata areas are in a mature stage in terms of petroleum exploration.

A few private oil firms have been conducting exploration activities. MITI (Ministry of International Trade and Industry) has sponsored exploration programs for domestic oil and gas resource development. A consecutive series of plans that were developed by MITI first started in 1955, and they have aided exploration work by private oil firms by providing geophysical reconnaissance surveys and stratigraphic wells (Tono, 1989). The current seventh plan is now underway and has special emphasis on the exploration of deep-seated "Green Tuff" and Cretaceous and Paleogene targets. As seen in figure 7 , the average total depth of exploratory wells is increasing accordingly. Most of the currently producing volcanic reservoirs have been found without seismic surveys because the topographic relief of the fields and the thick volcanic agglomerate rocks at shallower depths have prevented the acquisition of seismic information from deeper seated volcanic reservoirs.

At present, Japan has 3 offshore and approximately 25 onshore producing oil and gas fields. Representative oil and gas fields are shown in figure 8 . Their production history is shown in figure 9. Domestic oil and gas production in 1989 was $1,755 \mathrm{~kL} /$ day and 5.5 million $\mathrm{m}^{3} / \mathrm{day}$, respectively.

\section{Future exploration targets}

The exploration of clastic sections in onshore areas of Japan is generally recognized to have reached the mature stage, particularly in 

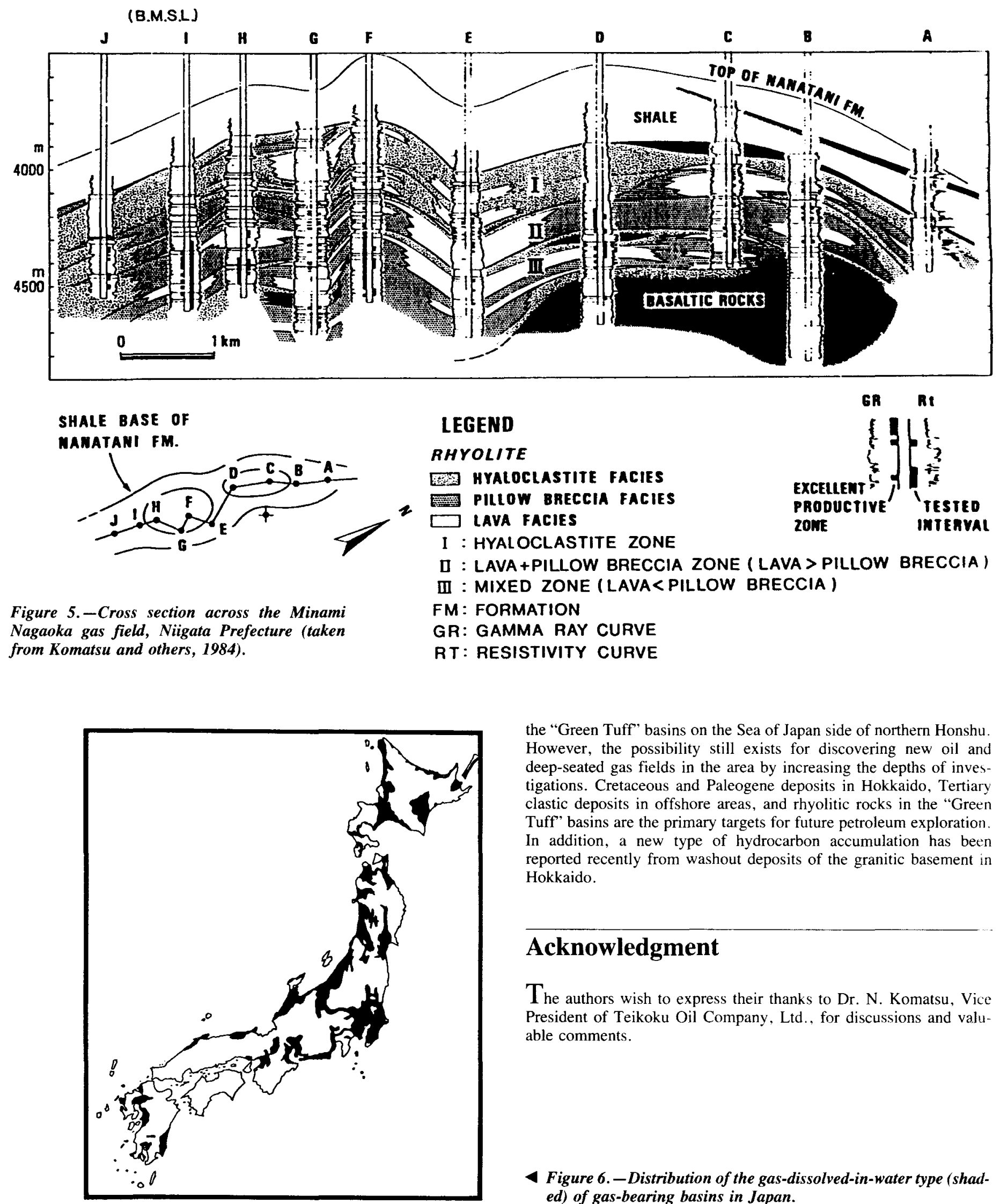

the "Green Tuff" basins on the Sea of Japan side of northern Honshu. However, the possibility still exists for discovering new oil and deep-seated gas fields in the area by increasing the depths of investigations. Cretaceous and Paleogene deposits in Hokkaido, Tertiary clastic deposits in offshore areas, and rhyolitic rocks in the "Green Tuff" basins are the primary targets for future petroleum exploration. In addition, a new type of hydrocarbon accumulation has been reported recently from washout deposits of the granitic basement in Hokkaido.

\section{Acknowledgment}

The authors wish to express their thanks to Dr. N. Komatsu, Vice President of Teikoku Oil Company, Ltd., for discussions and valuable comments.

Figure 6. -Distribution of the gas-dissolved-in-water type (shaded) of gas-bearing basins in Japan. 


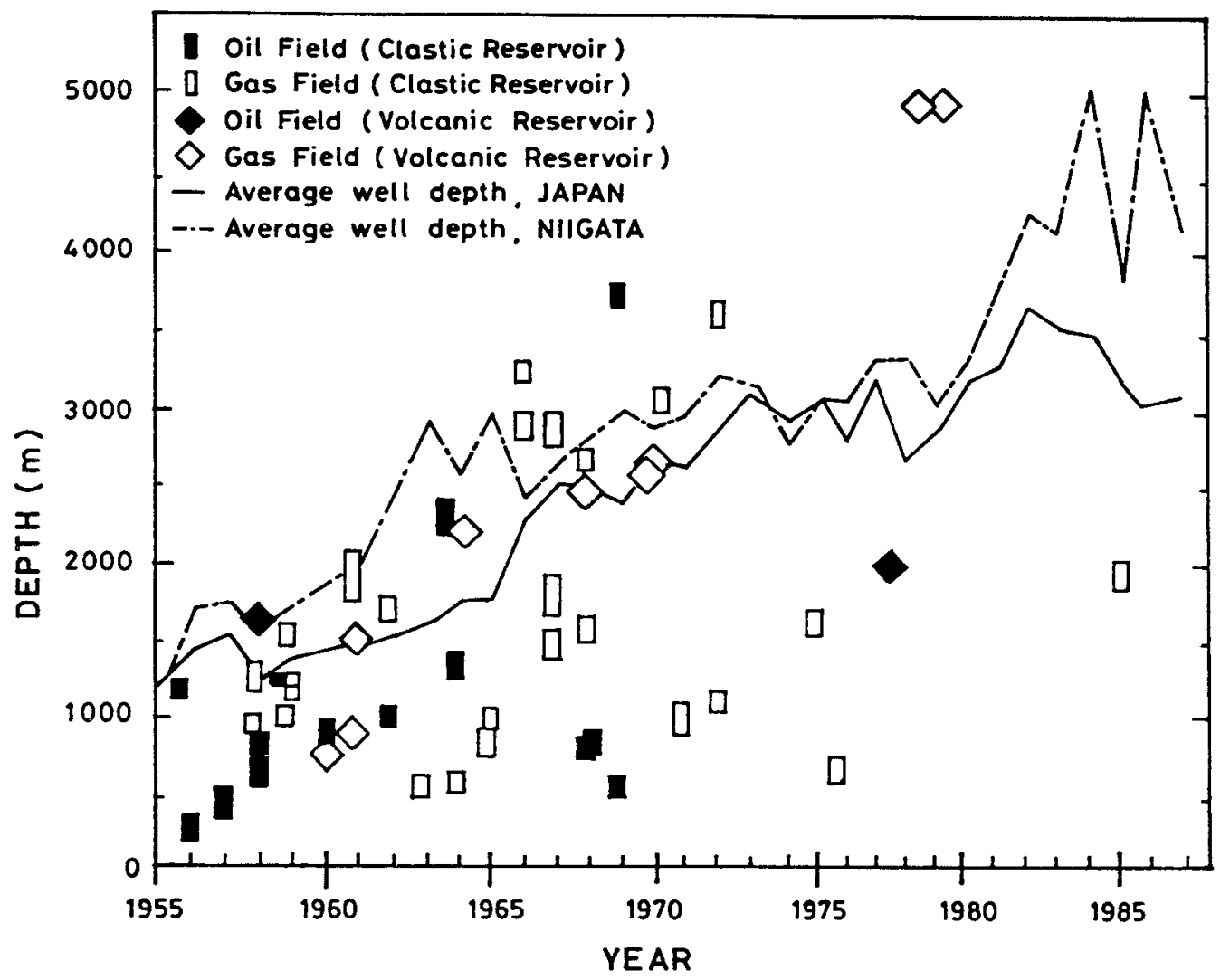

Figure 7.-History of average total depths of exploratory wells and oil and gas fields in Japan.
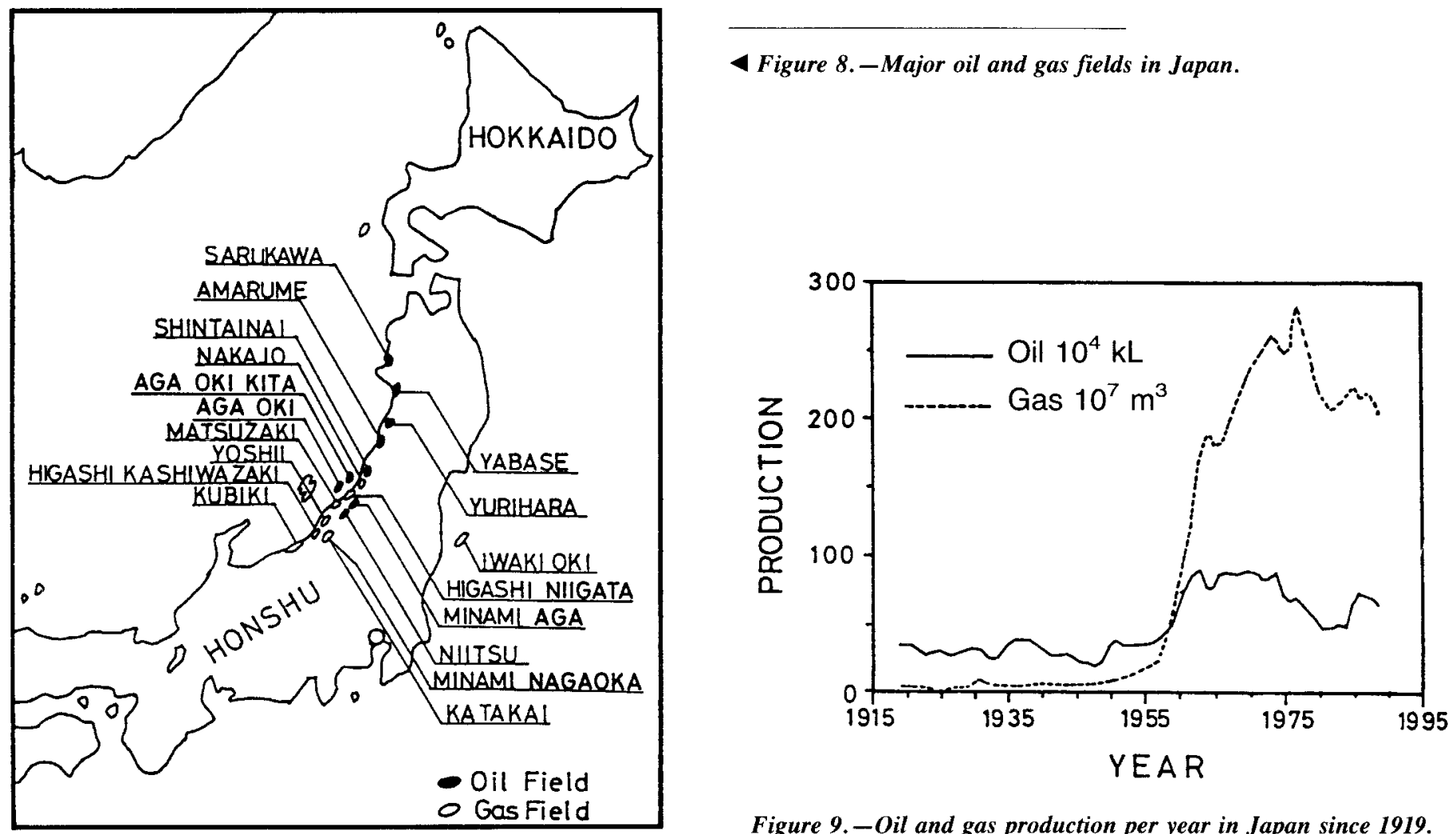

Figure 9. - Oil and gas production per year in Japan since 1919. 


\section{References}

Aoyagi, K., 1985, Origin of the Miocene carbonate reservoir rocks, Fukubezawa oil field, Akita province, northeast Honshu, Japan, in Roehl, P.O., and Choquette, P.W., eds., Carbonate petroleum reservoirs: New York, Springer-Verlag, p. 563-569.

Blow, W.H., 1969, Late middle Eocene to Recent planktonic foraminiferal biostratigraphy: International Conference on Planktonic Microfossils, 1st, Proceedings, v, 1, p. 199-421,

Dickinson, W.R., and Seeley, D.R., 1979, Structure and stratigraphy of forearc regions: American Association of Petroleum Geologists Bulletin, v. 63 , p. 1-33.

Fukuta, O., 1977, On the iodine-gas deposits of dissolved-in-water type with special reference to late Cenozoic stratigraphy of Japan, in Ujiie, H., and Saito, T., eds., International Congress on Pacific Neogene Stratigraphy, 1st, Tokyo, 1976, Proceedings, p. 332-334.

Ikebe, Y., and Maiya, S., 1981, Akita and Niigata areas, in Tsuchi, R., ed., Neogene of Japan; its biostratigraphy and chronology: IGCP Project 114, International Workshop on Pacific Neogene Biostratigraphy, Osaka, Japan, 1981, p. 68-75.

Ishiwada, Y., and Ogawa, K., 1976, Petroleum geology of offshore areas around the Japanese islands: Bangkok, United Nations Economic and Social Commission for Asia and the Pacific, CCOP Technical Bulletin, v. 10 , p. $23-34$.

Katahira, T., and Ukai, M., 1976, Petroleum fields of Japan with volcanicrock reservoirs, in Halbouty, M.T., Maher, J.C., and Lian, H.M., eds., Circum-Pacific energy and mineral resources: American Association of Petroleum Geologists Memoir 25, p. 276-279.

Komatsu, N., Fujita, Y., and Sato, O., 1984, Cenozoic volcanic rocks as potential hydrocarbon reservoirs: World Petroleum Congress, 11th, London, 1983, Proceedings: Chichester, UK, John Wiley, v. 2, p. $411-420$.

Marsden, S.S., and Kawai, K., 1965, "Suiyōsei-ten'nengasu," a special type of Japanese natural gas deposit: American Association of Petroleum Geologists Bulletin, v. 49, p. 286-295.

Nakai, N., 1960, Carbon isotope fractionation of natural gas in Japan: Journal of Earth Sciences, Nagoya University, v. 8, p. 174-180.

Tono, S., 1989, Review of petroleum exploration activities in Japan (October 1989): United Nations Economic and Social Commission for Asia and the Pacific, CCOP meeting, 26th, Bangkok, submitted on 26 October 1989.

Tsuchiya, N., Ozawa, A., and Katahira, T., 1989, Two types of Miocene basaltic rocks around Yurihara oil and gas field, southeastern Akita Prefecture, northeast Japan: Journal of the Japanese Association for Petroleum Technology, v. 54, p. 179-193.

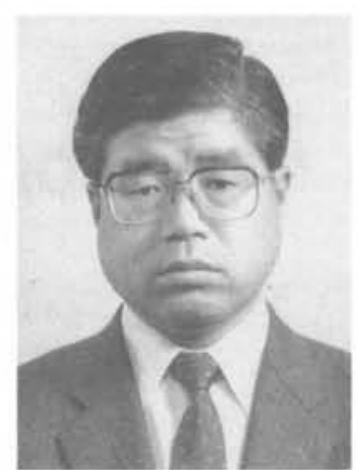

Yoshiro Kikuchi is currently Director and General Manager of the Exploration Department of Teikoku Oil Company, Lid. He received his bachelor's degree in geology from Akita University. He joined Teikoku Oil in 1959 as a geologist and has worked both inside and outside Japan, including in Malaysia, Alaska of the USA, and Nigeria. He served as a member of the Board of the Japanese Association for Petroleum Technology and also as Chairman of the Exploration Committee of the same association.

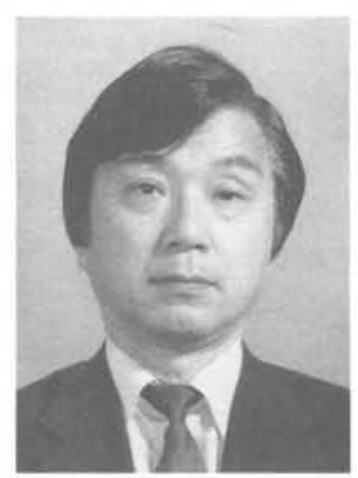

Satoshi Tono has been appointed as General Director of the Geological Survey Department of Japan National Oil Corporation (JNOC). He joined Teikoku Oil in 1964 as a geologist and has worked basically overseas, including in Malaysia, Indonesia, and Abu Dhabi of the United Arab Emirates. He was seconded to JNOC in February 1991. He received a bachelor's degree in geology from Tokyo University of Education, and he served as a member of the Board of the Geological Society of Japan.

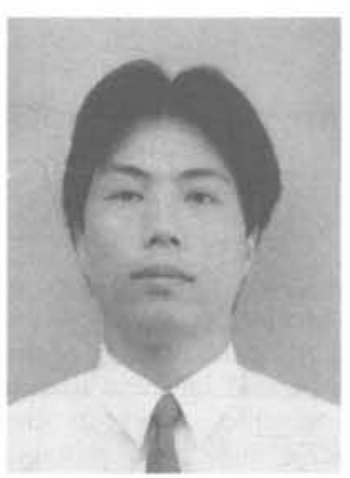

Masaaki Funayama received his bachelor's degree from Yamagata University in 1981 and a master's degree in geology from Tohoku University in 1983. He worked for 5 years for Teikoku Oil from 1983 to 1988, after which the company provided him the opportunity to study at Louisiana State University (LSU) in the USA. He received his second master's degree in geology from $L S U$ in 1990. He is currently a geologist at the Niigata District Office of Teikoku Oil. 